\title{
STUDENTS' PERSPECTIVE TOWARDS INTERNET IN ENGLISH LANGUAGE LEARNING AT SMPN 1 BUNTA
}

\author{
Abdul Rabbi Arrasul \\ Teacher Training and Education Faculty, Muhammadiyah University of Luwuk. \\ Email:aby_jovanovic@yahoo.co.id
}

\begin{abstract}
Abstrak
Tujuan dari penelitian ini adalah untuk mengetahui dan mendeskripsikan pandangan siswa terhadap internet dalam pembelajaran bahasa Inggris. Penelitian ini mengaplikasikan metode peneltian deskriptif dengan desain kualitatif. Populasi dari penelitian ini berjumlah 99 siswa kelas IX SMPN 1 Bunta yang tersebar di 6 kelas paralel. Sampel dari penelitian ini dipilih berdasarkan teknik random sampling, dimana tiga kelas diambil secara acak untuk dijadikan sampel. Kelas IX A, IX B dan IX C adalah sampel dar penelitian ini. Penelitian ini dilakukan dalam tiga kali pertemuan. Data dikumpulkan melalui angket. Data ini juga dianalisa dengan menggunakan rumus dimana $\mathrm{P}$ adalah persentasi angket, $\mathrm{F}$ adalah frekuensi dan $\mathrm{N}$ adalah jumlah sampel. Berdasarkan analisis data, hasil penelitian ini mengindikasikan bahwa $(100,00 \%)$ siswa mengenal istilah internet, $(77,78 \%)$ siswa dapat mengoperasikan atau menggunakan internet, $(95,96 \%)$ siswa setuju bahwa internet digunakan sebagai salah satu sumber belajar bahasa Inggris, $(61,62 \%)$ siswa setuju bahwa penggunaan internet sebagai sumber belajar dapat menambah penegtahuan mereka, $(60,61 \%)$ siswa merasa bahwa internet dapat meningkatkan keterampilan bahasa Inggris mereka dan $(46,47 \%)$ siswa setuju bahwa melalui internet, proses pembelajaran bahasa inggris lebih bervariasi. Ini berarti bahwa penggunaan internet dalam pembelajaran bahasa Inggris telah memberikan dukungan terhadap proses pembelajaran khususnya pembelajaran bahasa Inggris dimana siswa bisa menemukan informasi baru tentang bahasa Inggris, menyelesaikan masalah-masalah siswa dalam pelajaran bahasa Inggris, meningkatkan keterampilan bahasa Inggris dan mendaptkan pengalaman baru dalam pembelajaran bahasa Inggris secara cepat, tepat dan mandiri. Sementara itu, guru bahasa Inggris juga memiliki media untuk memperbaharui proses pengajaran mereka, sehingga proses pengajaran mereka menjadi lebih hidup, tidak monoton dan menarik. Ini membuktikan bahwa, kehadiran internet dalam pembelajaran bahasa Inggris dapat memberikan pengaruh positif terhadap siswa kelas IX di SMPN 1 Bunta. Oleh karena itu, siswa memiliki pandangan yang baik terhadap penggunaan internet itu sendiri di dalam pembelajaran bahasa Inggris.
\end{abstract}

Kata Kunci : Pandangan, Internet, Sumber Belajar dan Pengajaran Bahasa Inggris.

\section{Introduction}

Technology is an increasingly influential factor in education. Computers and internet are used in developed countries even developing countries both to complement established education practices and develop new ways of learning such as online education (a type of distance education). This gives students the opportunities to choose what they are interested in learning.

Now, we live in era of the computer, and there are so many growing demands on almost everyone, including teachers and students. We may already use computer programs to create materials for our students or to do task for our teacher, but we may feel confused, or intimidated, by the publicity about the internet. The internet for instance the net is known as cyberspace, the information superhighway, the online community, the electronic library and the digital revolution.

Internet is necessary. Wherever and whenever we are, internet is already exist and ready to access. Nowdays, we cannot just connect to the internet, go to google, type in our search query and instanly be looked at thousands of possible sources of good information. We can not only find what we look for locally, but we can connect on a global scale to find out how our subject matter is viewed all over the world. What used to take our days to produce has been cut down to minimize hours from the wasted of time in editing.

Based on the writer's experience, internet is one of learning media which is 
needed in learning process, especially in the English learning. Information about education field is up to date, looking for more learning sources are easy, and it can increase our knowledge. SMPN 1 Bunta was the place for the writer in conducting the research. He was intended to investigate or to know the student's perspective towards internet in English Language Learning even the school is in suburb area. It because, by looking the school situation that is really far from the Capital City of Banggai Regency, Luwuk. So, the writer thought that the students of SMPN 1 Bunta also use internet as one of their learning media wheather in school area or not, because there is an internet hotspot in the school area. To look the students' condition that most of them have mobile phone which can access internet well. There are also some students who have laptops. So, they can use the laptops to access internet too. The others also use internet media (warnet) that are available around Bunta. The developing of technology and the internet's usage which develop rapidly in education can make the students must follow that condition, in this case, the use of internet in learning, especially in English language learning.

Therefore, through this research's title The Students' Perpective towards Internet in English Language Learning at SMPN 1 Bunta the writer invited and shared to the reader to look and know the students' perpectives towards internet in English learning.

\section{Information and Communication Technology}

Technology is an increasingly influential factor in education. Computers and mobile phones are used in developed countries both to complement established education practices and develop new ways of learning such as online education (a type of distance education). It provides students with the opportunity to choose what they are interested in learning. The proliferation of computers also means the increase of programming and blogging. Technology offers powerful learning tools that demand new skills and understandings of students, including Multimedia, and provides new ways to engage students, such as Virtual learning environments. Effective technology programs encourage students to be productive, innovative and enterprising that involve generating ideas and talking action as well as developing techniques and products that satisfy human needs.

Information technology (IT) is the acquisition, processing, storage and dissemination of vocal, pictorial, textual and numerical information by a microelectronicsbased combination of computing and telecommunications. We shall call it information technology.

In short, anything that renders data, information or perceived knowledge in any visual format whatsoever, via any multimedia distribution mechanism, is considered part of the domain space known as Information Technology (IT). Generally, Lucas (2000: 13):

Teknologi informasi adalah segala bentuk teknologi yang diterapkan untuk memproses dan mengirimkan informasi dalam bentuk elektronis, mikro computer, computer mainfarame, pembaca barcode, perangkat lunak memproses transaksi, perangkat lunak lembar kerja (worksheet) dan peralatan komunikasi dan jaringan merupakan contoh informasi teknologi.

Communication technology is electronic systems that are used for communication between individuals or groups. Communication technology facilitates communication between individuals or groups who are not physically present at the same location. Systems such as telephones, telex, fax, radio, television, and video are included, as well as more recent computer-based technologies, including electronic data interchange and e-mail. Munir (2008: 14), "Teknologi komunikasi adalah perangkat teknologi yang terdiri dari hardware, software, proses dan system, yang digunakan untuk membantu prosese komunikasi, yang bertujuan agar komunikasi berhasil (komunikatif)".

The Use of ICT in Teaching and Learning Process

Information and Communication Technology are the acquisition, processing, storage and dissemination of vocal, pictorial, textual and numerical information by electronic system that is used for communication between individuals. The use of ICT as medium focuses on the use of ICT for the enhancement of the teaching learning 
process of students. By means of ICT students can achieve their learning goals more effectively. Within teacher education there is overlap between the use of ICT as aspect and as medium. A teacher educator, who uses ICT for the enhancement of the learning process of his students, also shows students at the same time how ICT can be used in primary education. Considering the role of the teacher in education institutes are expected to fulfil, it is important that a teacher educator provides his students (future primary and secondary teachers) with 'good' examples. ICT is not just regarded as a tool, which can be added to or used as a replacement of existing teaching methods. Marjolein \& Martina (2007: 188) state "ICT is seen as an important instrument to support new ways of teaching and learning". ICT should be used to develop student's skills for cooperation, communication, problem solving and life long learning.

\section{Definition of Internet}

Internet is a network of people and information, linked together by telephone lines which are connected to computers. In fact, more than 100,000 independent networks public and private - are currently connected to form this vast global communication system. This is the 'road' of information superhighway. Rajashekar (2004: 3) states "Internet is Interconnection of computers and computer networks using TCP/IP communication protocol". Internet is also a global system of interconnected computer network that use the standard internet protocol suite to serve billions of uses worldwide. It is a network of networks that consists of millions os private, public, academic, business, and government networks of local to global scope that are linked by a broad array of electronic, wireles and optical networking technologies.

Today, the internet is a public, cooperative, and self sustaining facility accessible to hundreds of millions of people worlwide. Physically, the internet uses a portion of the total resources of the currently existing public telecommunication networks. Technically, what distinguish the internet is its use.

\section{Positive and Negative Impacts of Internet on Education}

There are several positive and negative impacts of the internet on education. For rural areas especially, the acces to information that the internet offers is an incredible positive force, allowing almost anyone to find the answer to basic questions simply and easily. " It help education in that when someone curious about something (and therefore open to learn), they can find out some information to feed that "learning hunger" immediately" (Rob Callahan,2). Here are some positive and negative impacts as follow:

A. Positive Impacts

1) More opportunities to explore the subject you want to study, because of the many and varied materials available in the net.

2) The tremendous amount of knowledge available at one platform.

3) A student becomes global. So, he/she will not limit his/her knowledge to one book, or a little of the experiences.

4) Increases inquisitiveness in children, thus creating better interests in studies.

5) Research works become faster.

B. Negative Impacts

1) Because of many given choices, there is tendency for one to get confuse. Not all that is in the net are official and true.

2) It is very difficult to monitor the internet usage very closely. This leaves a scope of of children being lured into harmful stuff like pornography.

3) Less visit to the library and less scanning of real book. So, it looses the love for genuine reading.

4) Giving children quick stuff like internet may remove their interest in libraries and reading printed books.

5) The tendency for one to become impatient to things that one needs to get, like research works, and assignments. Because of that, it called "INSTANT" answer one can have in the net.

\section{Internet and the Relation to Academic}

Generally, internet is identified as the glamour life style and the centre of negative contents. News about pornography and celebrity's scandals will get easily. The result, internet is always seen as a thing that break the student's moral. Enterprise (2010: 1) states "Dengan memanfaatkan internet secara sederhana semudah mencari informasi di internet, kita bisa menemukan sumber ilmu 
pengetahuan yang sangat berharga". Whatever the problems that we get from the school, it will be finished through internet's help.

The internet must be balanced among academic. It makes some features of the profession less complicated, like the possibility of doing homework, it also enchances a demand for extensive availibility. The use of internet increases student's knowledge and less the difficulties that they get in academic by balancing both of them.

\section{Internet in Improving English Language} Skill

As the main communication tool, language also takes an important role in process to spread science to the society. Enterprise (2010: 1) says that "Penguasaan bahasa Inggris dan bahasa asing lainnya mutlak diperlukan dalam dunia pendidikan untuk menyerap pengetahuan dan teknologi baru yang berasal dari luar negeri". Now, the appearance of some sites such as Google Translate, Yahoo Babelfish, Sederet.com, and WorldLingo which provide the translation services, step by step can solve the language problem. Through these sites, we can improve our English language skill and improve the vocabularies that we have. Therefore, we need to thanks to internet, many more language resources are now widely available for everyone to enjoy. There are number of sites and groups dedicated to English language where you can find study materials and meet others learning the same language.

Surfing on the internet has been the most popular way to learn English because it is convenient as well as entertaining. It saves a lot of time. Some websites provide beautiful illustrations to learn english. A few websites supply amusing games and online language exercise to attract netizen's attention thereby heling them learn English effectively. For example, ALE website teaches many vocabularies through an interesting game called 'English Sharp Shooter'. The websites, www.askoxford.com, clarifies the doubts asked by the netizens. Then, the netizens would listen to the online radio to train their listening comprehension without spending money to buy CDs. Another website, www.englishdaily626.com provides very useful information about the English language.

\section{METHOD}

\section{Design of Research}

The writer used descriptive research method in his research. In connecting to the research, the writer described the students' perspective towards internet in English Learning to the grade students. He analyzed the data use qualitative method.

\section{Population and Sample}

The population of this research was the the grade IX students of SMPN 1 Bunta. Those students were divided into six parallel classes. There were 31 up to 34 students from each of the parallel class. To got the sample the writer used random sampling or put all the number of population in a paper then shaked it to determine the sample. The writer got class IXA, IXB, and IXC. So, the numbers of the sample was 99.

\section{Instrument of Data Collection}

The researcher used three instruments. First was observation checklist, the purpose of observation checklist was to know the situation of the learning process that related to the use or the role of internet. The second was questionnaire, the writer used questionnaires to gain accurate data. The kind of questionnaires which is applied was called closed questionnaire. A closed questionnaire is a questionnaire which provide questions and options. The students filled the questionnaire based on the questions and choose the options given. The questionnaire consisted of ten questions. The last instrument was interview, it is aimed to get the additional information wheather the English teacher used internet as one of the source of English teaching or not.

\section{Technique of Data Analysis}

The writer used descriptive analysis in analyzing the data. $\mathrm{He}$ analyzed the questionnaire from the students' sheets. He described the questionnaire results.

The writer computed the percentage of student's responses from questionnaire. He applied the formula as proposed by Hatch and Farhady (1982: 92) as follows: 


$$
\mathrm{P}=\frac{F}{N} \times 100 \%
$$

Where :

$\mathrm{P}=$ Percentage from questionnaire

$\mathrm{F}=$ Frequency

$\mathrm{N}=$ Number of students

\section{Data Presentation and Analysis} The Result of Observation and Interview

The observation and interview were done before arranging the project of the Skripsi. The purpose of observation was too see directly the situation/condition of the school with its existence to the use of internet in teaching learning prosess and to know how the teacher facilitates the students in learning english by using technology (internet). So, the writer could be easy to ask more about the student's perspective. While interview was done to support the result of questionnaire.

1) There is an internet hotspot in the school area that support the teaching learning process especilly in English language learning.

2) There is also some internet facilities "WARNET" near of the school that support the students in English language learning.

3) The students use internet five times a month to learn English and finish their English task.

4) The english teacher gives some tasks that related to the use of internet such as reading passage, vocabulary, etc.

5) The students usually do their task by using internet.

6) The students feel enjoy and extensive to do their english task on internet.

7) The English teacher uses that internet is needed to update her learning resources. By updating her learning resource, it can make her ways to teach and material become life, not monotonous and the students can enjoy to learn English.

8) The English teacher thinks that one of the internet's role in English language learning is to make the learning process becomes wider. Because, the students have another chance to learn English and do not stay in one or few books.

9) The English teacher uses internet to update her learning resources at least twice a week.
10) Internet takes an important role in English language learning. Because, it serves the students who want to learn English globally and many various features in internet that can improve the student's English skill.

11) To make the students become technologically students, the English teacher has a part in this process. By giving a task that related to the use of internet, but not as the main way.

12) Internet is able to supports another way to learn English, not only at school, library even from book. Internet can give another creative way to learn English.

Both students and teachers, they have the same problems in facilitating themselves in learning with Internet because the school still limits the use of Internet Network, so they cannot access Internet freely.

\section{Research Findings (The Result of Questionnaire)}

The questionnaire in the research was intended to give more information about the students' perspective towards Internet in English Language Learning. So, the sudents were expected to choose the answer based on what they perceived and though as follow: (1) Do the students often listen internet terms, (2) Can the student operate internet, (3) Must internet be used as one of learning resources at school, (4) why does internet must be used as one of learning resource especially in English learning, (5) In the relation to the English language learning, what do the students expect from the internet's role, (6) What English skill do the students feel increased when using internet in English language learning, (7) Why the students love internet as one of media in English learning, (8) Is internet useful for English learning process, (9) The place that students like when browsing internet, (10) Tool that the students usually use to browse internet. The questionnaire was given on, Tuesday $23^{\text {rd }}$, Thursday $24^{\text {th }}$, and Friday $25^{\text {th }}$ of August, 2016. The result of questionnaire can be seen below:

\section{Do the student often listen internet term?}

The first question that was given to the students (responders) were "Do the student often listen internet term?". There were three 
options prepered. They were (a) often, (b) seldom, and (c) never.

Table 1. Do the student often listen internet term

\begin{tabular}{|l|c|c|}
\hline Option & Frequency & $\begin{array}{c}\text { Percentage } \\
(\%)\end{array}$ \\
\hline a. Often & 99 & 100.00 \\
b. Seldom & 0 & 0.00 \\
c. Never & 0 & 0.00 \\
\hline Total & 99 & 100.00 \\
\hline
\end{tabular}

Table1 shows that all responders $(100.00 \%)$ stated that they often listen the internet terms. It because the existence of internet which is very familiar in this era. This question is a key to ask more their perspective towards internet in English learning in the next question.

\section{Can the student operate internet?}

The second question that given to the students (responders) were "Can the student operate internet?". There were three options that also prepared. They were (a) can, (b) litle bit, and (c) cannot.

Table 2. Can the student operate internet

\begin{tabular}{|l|c|c|}
\hline \multicolumn{1}{|c|}{ Option } & Frequency & Percentage (\%) \\
\hline a. Can & 77 & 77.78 \\
b. litle bit & 20 & 20.20 \\
c. cannot & 0 & 0.00 \\
\hline \multicolumn{1}{|c|}{ Total } & 97 & 100 \\
\hline
\end{tabular}

Table 2 shows that most of the students (77.78\%) answered that they can operate internet because they have their own tools to access internet. there were also some students $(20.20 \%)$ who answered that they little bit know how to use and operate internet. It because they do not have tools to access internet and their house are far from the internet facilities "WARNET". It makes them rarely to have a chance to operate or use internet. In this question, there were only two or $(2.02 \%)$ did not answer the question.

\section{Must internet be used as one of learning resources at school?}

The third question that given to the students (responders) were "Must internet be used as one of learning resources at school?". There were three options that also prepared. They were (a) internet needs to use as one of learning resources at school, (b) internet less needed to use as one of learning resources at school, and (c) internet does not need to use as one of learning resources at school.

Table 3. Must internet be used as one of learning resource at school

\begin{tabular}{|c|c|c|}
\hline Option & Frequency & $\begin{array}{c}\text { Percentage } \\
(\%)\end{array}$ \\
\hline $\begin{array}{l}\text { a. internet } \\
\text { needs to use } \\
\text { as one of } \\
\text { learning } \\
\text { resources at } \\
\text { school }\end{array}$ & 95 & 95.96 \\
\hline $\begin{array}{l}\text { b. internet less } \\
\text { needed to } \\
\text { use as one of } \\
\text { learning } \\
\text { resources at } \\
\text { school }\end{array}$ & 3 & 3.03 \\
\hline $\begin{array}{l}\text { c. internet does } \\
\text { not need to } \\
\text { use as one of } \\
\text { learning } \\
\text { resources at } \\
\text { school }\end{array}$ & 0 & 0.00 \\
\hline Total & 98 & 100 \\
\hline
\end{tabular}

Table 3 shows that most of the students $(95.96 \%)$ said that internet needs to use as one of learning resources at school. It is because, by seeing the advantages of internet which can make learning process become easy, faster, and they can get so many informations that they do not find at school or book. There were also students $(3.03 \%)$ said that internet less needed to use as one of learning resources at school. Some factors that make them said like that is they have limeted information about the advantages of internet in learning and they feel that learn by internet is compilcated. In this question, there was only one or $(1.01 \%) \mathrm{did}$ not give an answer.

The reason of the most students who said that internet is needed to use as one of learning resources at school can be seen from the student's answers that was given in the next question.

Why internet must be used as one of learning resources especially in English learning?

If the students already said that internet needs to use as one of learning 
resources at school. So, the next question that was given to the students are "The student's reason why internet must be used as one of learning resources especially in English learning?".

There were three options that also prepared. They were (a) adding more knowledges, (b) helping to finish a task, and (c) getting the new information accurately.

Table 4. Why internet must be used as one of learning resources especially in English learning

\begin{tabular}{|c|c|c|}
\hline Option & Frequency & $\begin{array}{c}\text { Percentage } \\
(\%)\end{array}$ \\
\hline $\begin{array}{l}\text { a. adding more } \\
\text { knowledges }\end{array}$ & 61 & 61.62 \\
\hline $\begin{array}{l}\text { b. helping to } \\
\text { finish a task }\end{array}$ & 18 & 18.18 \\
\hline $\begin{array}{l}\text { c. getting the } \\
\text { new }\end{array}$ & & \\
\hline $\begin{array}{l}\text { information } \\
\text { accurately }\end{array}$ & 20 & 20.20 \\
\hline Total & 99 & 100 \\
\hline
\end{tabular}

Table 4 shows that $(61.62 \%)$ students answered the question why internet must be used as one of learning resources espicially in English language because it can add their knowledge. Because, the more knowledge that they got from internet can help them to solve their problem that they got in school. While $(20.20 \%)$ students said that through internet they can get new information accurately about English because they thought that sometimes they need the new and fresh information that they never find in school or book. There were also $(18.18 \%)$ students said that internet can help them to finish their task that they got from the school.

In the relation to the English language learning, what does the student expect from the internet's role?

The fifth question that was given to the students (responders) were "In the relation to the English language learning, what does the student expect from the internet's role?". There were three options that also prepared. They were (a) adding more vocabularies, (b) improving English skill, and (c) helping to solve the English language learning problem.
Table 5. In the relation to the English language learning, what do the students expect from the internet's role

\begin{tabular}{|c|c|c|}
\hline Option & $\begin{array}{c}\text { Frequenc } \\
\mathrm{y}\end{array}$ & $\begin{array}{c}\text { Percenta } \\
\text { ge }(\%)\end{array}$ \\
\hline $\begin{array}{l}\text { a. adding more } \\
\text { vocabular } \\
\text { ies }\end{array}$ & 7 & 7.07 \\
\hline $\begin{array}{l}\text { b. improving } \\
\text { English } \\
\text { skill }\end{array}$ & 60 & 60.61 \\
\hline $\begin{array}{ll}\text { c. helping to } \\
\text { solve } \\
\text { English } \\
\text { language } \\
\text { learning } \\
\text { problem } \\
\end{array}$ & 32 & 32.32 \\
\hline Total & 99 & 100 \\
\hline
\end{tabular}

Table 5 shows that most of the tenth grades students $(60.61 \%)$ said that something they expect from the internet's role in English language learning are internet can improve their English skill. They said that many internet's features and sites that can help them to practice their English skill wheather writing, reading or vocabulary. While (32.32\%) students answered that internet can help them to solve their English language learning problem. The others $(7.07 \%)$ said that learning through internet can add more their vocabularies mastery.

What English skill does the students feel increased when using internet in English language learning?

After given a question about what do the students expect from the internet's role. The fact that most of the students answered that internet can improve their English skill. So, the next question that was given must be related to the previous question.

The question was "What English skill does the students feel increased when using internet in English language learning?". There were three options that also prepared. They were (a) writing, (b) reading, and (c) vocabulary. 
Table 6. What English skill does the student feel increased when using internet in English language learning

\begin{tabular}{|c|c|c|}
\hline Option & $\begin{array}{c}\text { Frequenc } \\
\text { y }\end{array}$ & $\begin{array}{c}\text { Percentage } \\
(\%)\end{array}$ \\
\hline a. writi & 11 & 11.11 \\
ng & 41 & 41.41 \\
b. readi & 46 & 46.46 \\
ng \\
c. voca \\
bul \\
ary
\end{tabular}

Table 6 shows that there were little bit diffrences between students who felt that when they use internet, their English skill can improve. (46.46\%) students answered that vocabulary becomes the most skill that can improve when they use internet. Because many of them said that there are many new English words and idioms that they got even reading should be the first skill. But they did not focus in their reading comprehension. (41.41\%) students said that reading becomes first skill that that can improve. It because some of said that by reading they will get more vocabularies. There were some students $(11.11 \%)$ said that their writing skill can improve whem they use internet as English learning resources. It because some of them have some accounts that support them to improve their writing skill such as email, facebook, and ect. So, they can practice their English to communicate with others people globally by chatting. While there was only one or $(1.01 \%)$ student has no choice.

\section{Why do the students love internet as one of} media in English learning?

After given a queastion about English skill, then the writer also asked about their enjoyment to lean English through internet.

The next question that given to the students (responders) are "Why do the students love internet as one of media in English learning?". There were three options that also prepared. They were (a) learning becomes more various, (b) simple and easy, and (c) faster and no need to open any book.
Table 7. Why do the student loves internet as one of media in English learning?

\begin{tabular}{|c|c|c|}
\hline Option & Frequency & $\begin{array}{c}\text { Percentag } \\
\text { e }(\%)\end{array}$ \\
\hline $\begin{array}{l}\text { a. learning } \\
\text { become } \\
\text { s more } \\
\text { various }\end{array}$ & 46 & 46.47 \\
\hline $\begin{array}{l}\text { b. simple and } \\
\text { easy }\end{array}$ & 30 & 30.30 \\
\hline $\begin{array}{l}\text { c. faster and no } \\
\text { need to open } \\
\text { any book }\end{array}$ & 23 & 23.23 \\
\hline Total & 99 & 100 \\
\hline
\end{tabular}

Table 7 shows that most of students $(46.47 \%)$ said that through internet, English learning becomes more various. It was cased by the development of technology especially internet which can serve them another style to learn English not only from the book. There were also $(30.30 \%)$ students who said that learning English through internet is simple and easy. While $(23.23 \%)$ students said that learning through internet is faster and they do not need to open any book to find or to solve their English language learning problems.

\section{Is internet useful for English learning process?}

The eighth question that given to the students (responders) were "Is internet useful for English learning process?". There were three options that also prepared. They were (a) useful, (b) less useful, and (c) unseful.

Table 8. Is internet useful for English learning process?

\begin{tabular}{|l|c|c|}
\hline \multicolumn{1}{|c|}{ Option } & Frequency & $\begin{array}{c}\text { Percentage } \\
(\%)\end{array}$ \\
\hline a. useful & 99 & 100.00 \\
b. less useful & 0 & 0.00 \\
c. unuseful & 0 & 0.00 \\
\hline \multicolumn{1}{|c|}{ Total } & 99 & 100 \\
\hline
\end{tabular}

In this question, table 8 shows that all the students $(100.00 \%)$ stated that internet is useful in English language learning as learning resources even there were some of them have not used it yet maximally in their english learning process wheather in school area or outside of the school area. 
The place that the students like when browsing internet

After asking all students perpective towards internet in English language learning and the advanteges of internet as English learning resources, the writer asked them about the habitual of the student in accessing or browsing internet and their beloved place to access internet.

The nineth question that given to the students (responders) were "The place that the students likes when browsing internet?". There were three options that also prepared. They were (a) at home, (b) at school, and (c) at "WARNET. Look the result in table 11.

Table 9. The place that the students like when browsing internet

\begin{tabular}{|l|c|c|}
\hline Option & Frequency & $\begin{array}{c}\text { Percentage } \\
(\%)\end{array}$ \\
\hline a. at home & 25 & 25.25 \\
b. at school & 13 & 13.13 \\
c. at & 61 & 61.62 \\
\multicolumn{1}{c|}{ "WAT" } & & \\
\hline Total & 99 & 100 \\
\hline
\end{tabular}

In table 9 , most of the students $(61.62 \%)$ answered that they usually access or browse internet at "WARNET". Because most of them do not have their own tools to access internet. The others $(25.25 \%)$ answered that if they want to access or browse internet, they prefer to access it at home. Because some of them have their own tools to access internet at home like speedy through WIFI network. While (13.13\%) students answered that they access internet at school area. Because the school also gives them facility and it can save their money. What tool do the students usually use to browse internet?

The last question that the witer gave to the tenth grade students were "What tool that the students usually use to browse internet?". There were three options that also prepared. They were (a) mobile phone, (b) laptop, and (c) computer.
Table 10. What tool do the students usually use to browse internet?

\begin{tabular}{|l|c|c|}
\hline Option & Frequency & $\begin{array}{c}\text { Percentage } \\
(\%)\end{array}$ \\
\hline a. mobile & 37 & 37.37 \\
phone & & \\
b. laptop & 24 & 24.25 \\
c. computer & 38 & 38.38 \\
\hline Total & 99 & 100 \\
\hline
\end{tabular}

Table 10 shows more various answers. There were $(38.38 \%)$ students who answered that they use computer when browsing in internet. (37.37\%) students answered that they use mobile phone such as BlackBerry to access internet and the others $(24.25 \%)$ answered that they use laptop to acces internet.

\section{Discussion}

The existence of internet in school area or out of school area is very supporting in learning process especially in English learning, where the students can find new information about English, solving their English problems, improving their English skill, and having new experience in learning English fastly, accurately, and independently. While the English teachers have media to update their learning process in order their teaching learning process become life, not monotonous and exciting.

\section{Conclusions}

After doing the research, observing, interviewing, giving the questionnaire, and analyzing the data from the students during research, the writer came to the conclusions that:

1) Most of the students there (100.00\%) said that they often listen the internet terms.

2) $(77.78 \%)$ students of grade IX answered that they can operate or use internet.

3) $(95.96 \%)$ students said that internet is needed to use as one of English learning resources at school.

4) $(61.62 \%)$ students gave reason why internet must be used as one of learning resources especially in English language learning because it can add their knowledges.

5) Most of the grade IX students (60.61\%) answered that their expectations to the internet's role in English language 
learning are internet can improve their English skills.

6) $(46.46 \%)$ students answered that vocabulary becomes the most skill that can improve when they use internet in learning English.

7) (46.47\%) students said that through internet, their English learning become more various.

8) All the students $(100.00 \%)$ said that internet is usefull in English language learning.

9) Most of the students (61.62\%) answered that they usually acces or browse internet at "WARNET".

10) While $(38.38 \%)$ students answered that they use computer when they access internet.

Those can prove that the grade IX students at SMP Negeri 1 Bunta have positive perspectives towards internet English language learning, open their mind towards the development of technology (internet) in globalization era, and have big expectations towards internet for being one of their English learning resouces legally.

\section{Suggestions}

1) By looking the potentials and the effects when internet is used programly in English language learning activity, it is the time for the students to begin the serious effort in the internet usage to the importance of learning activity especially English language learning activity at school.

2) The teachers are expected to be able to plan the internet usage in their English language learning activity regularly in order to the students can have learning experiences from the learning resources besides teachers and book.

3) For the next researcher who takes the same research, to be more creative to find out some ways to make this research maximally progress in the future, and if you want to prove the result of this research, the writer suggests you to take the experimental research in your next research.

\section{REFERENCES}

Ally. M. (2009). Mobile Learning: Transforming the Delivery of Education and Training. 1200, $10011-109$ Street Edmonton, AB T5J 3S8: AU Press, Athabasca University.

Dhanta, R. (2008). Panduan Browsing Internet. Surabaya: Penerbit Indah.

Drent. M. \& Meelissen. M. (2007). Which Factors Obstruct or Stimulate Teacher Educators to Use ICT Innovatively?. AE Enschede, Netherlands: University of Twente

Enterprise, J. (2010). Meningkatkan Prestasi Akademik dengan Internet. Jakarta: PT Elex Media Komputindo.

Fanani, A. (2008). Anak Cerdas dengan Dunia Maya. Banguntapan, Bantul, Jogjakarta: Image Press.

Hatch \& Farhady, (1982). Research Design and Statistic for Applied Linguistic. Massachusetts, Newbury House Publisher.

Kibby, M. ( 1999). Assessing Student Online. The University of New Castle. Tersedia: http://www.newcastle.edu.au/departemen t/so/asses.htm.

[Retrieved on August 06, 2016]

Kozma, R.B. (1991). Learning with Media. Michigan: University of Michigan.

Krol, E. (1994). The Whole Internet. Sebastopol, CA: O'Reilly \& Associates, Incorporated.

Leary, A. (2010). The

Importance of Internet
to

Education.http://www.ehow.com/facts_5 758670 importanceinterneteducation.ht $\underline{m l}$

[Retrieved on August 10, 2016]

Rajashekar. T.B. (2004). Introduction to Internet. Bangalore: Indian Institute of Science.

Retalis. S. \& Papasalouros. A. (2001). eLearning Resource Brokers. Piraeus, Greece: University of Piraeus.

Sreenatachary, V. (2011). Using Internet in Improving One's English language Skill: 50 Informative, Educative \& Entertaining Websites. $\quad$ http://www.thecriterion.com/V2/n2/Sreenathachary.pdf [Retrieved on August 20, 2016]

Sugiyono, (2010). Metode Penelitian Kuantitatif, Kualitatif, dan $R \& D$. Bandung: Alfabeta 